\title{
KEMAMPUAN PRESENTASI DALAM MEMASARKAN PRODUK USAHA
}

\author{
Yusuf Hamdan', Anne Ratnasari ${ }^{2}$ \\ ${ }^{1,2}$ Fakultas Ilmu Komunikasi Universitas Islam Bandung \\ Jl. Tamansari No. 1, Telp. (022) 4264070, Bandung 40116 \\ No. Telp./HP: ${ }^{1} 08122340215,{ }^{2} 081224506506$ \\ E-mail: ${ }^{1}$ yusuf.hamdan@gmail.com, ${ }^{2}$ anneratnasari10@gmail.com
}

Naskah diterima tanggal 5 Oktober 2016, direvisi tanggal 4 November 2016, disetujui tanggal 17

November 2016

\section{PRESENTATION SKILLS IN MARKETING BUSINESS PRODUCT}

\begin{abstract}
One aspect of supporting the advancement of the business including the ability of employers to present products or services offered, as potential consumers to feel confident to buy or use the product or service. This study aimed to analyze the preparation of the presentation, the presentation of the message presentation and supporting elements presentations to market the business. Qualitative research methods used in this study with data analysis techniques in the form of case studies. The informants were women entrepreneurs officials Indonesian Business Women Association (IWAPI), West Java. This study found the presenter presenting business products through the preparation, presentation of the message, and the presentation of the supporting elements. Preparation presentation presenter recovered had to prepare a presentation in writing or spontaneously, to make headlines. At the presentation of the message consists of an introductory presentation, content, and conclusions. Presenter maintains visual contact with the audience, using the motion of the body (face and hands), in addition to the process of presenting the message presentation using word articulation orderly and clear. Meanwhile, at the close of the presentation, the presenter concluded overview presentation and encouraged the audience to buy or use the product business has to offer. In the presentation supporting elements, the study found the presenter using the product or service demonstrations, customer testimonials and involves the use of video and images in the presentation.
\end{abstract}

Keywords: business presentation, women entrepreneurs, markets, products, and services.

Abstrak. Salah satu aspek pendukung dalam kemajuan bisnis antara lain kemampuan pengusaha mempresentasikan produk atau jasa yang ditawarkan, sebagai calon konsumen merasa yakin membeli atau menggunakan produk atau jasa tersebut. Penelitian ini bertujuan untuk menganalisis persiapan presentasi, penyajian pesan presentasi, dan unsur pendukung presentasi untuk memasarkan produk usaha. Metode penelitian kualitatif digunakan dalam penelitian ini dengan teknik analisis data berupa studi kasus. Informan penelitian adalah wanita pengusaha pengurus Ikatan Wanita Pengusaha Indonesia (IWAPI) Jawa Barat. Penelitian ini menemukan presenter mempresentasikan produk usaha melalui persiapan, penyajian pesan, dan unsur pendukung presentasi. Persiapan presentasi di dalamnya ditemukan presenter menyiapkan materi presentasi secara tertulis atau spontan, membuat headline. Pada penyajian pesan presentasi terdiri dari pengantar, isi, dan simpulan. Presenter memelihara kontak visual dengan audiens, menggunakan gerakan tubuh (wajah dan tangan), selain itu pada proses penyajian pesan presentasi menggunakan artikulasi kata yang teratur dan jelas. Sedangkan 
pada penutupan presentasi, presenter menyimpulkan ikhtisar presentasi dan mendorong audiens untuk membeli atau menggunakan produk usaha yang ditawarkan. Pada unsur pendukung presentasi, peneliti menemukan presenter menggunakan demonstrasi produk atau jasa, melibatkan kesaksian pelanggan dan penggunaan video serta foto dalam presentasi.

Kata kunci: presentasi bisnis, wanita pengusaha, memasarkan, produk, dan jasa.

\section{PENDAHULUAN}

Wanita pengusaha turut berperan dalam memajukan masyarakat, karena aktivitas mereka dapat membantu wanita berpenghasilan dalam keluarga. Seperti yang dijelaskan oleh Yohana Yambise sebagai Menteri Pemberdayaan Perempuan dan Perlindungan Anak RI, bahwa wanita Indonesia mampu mengurangi angka pengangguran dan tanpa harus meninggalkan rumah, mereka bisa berproduksi (Sukiswanti, 2014b). Di Jawa Barat, wanita pengusaha yang tergabung dalam Ikatan Wanita Pengusaha Indonesia sekitar 1.200 orang. Mayoritas anggotanya memiliki skala usaha mikro $(85 \%)$, pengusaha menengah (12\%), dan pengusaha besar (3\%) (Sukiswanti, 2014a). Beragam jenis usaha dikembangkan mereka, baik di bidang produk dan jasa (Ikatan Wanita Pengusaha DPD Jawa Barat, n.d.).

Duarte dalam (Gallo, 2010) menjelaskan, kesuksesan bisnis sangat besar didukung oleh keterampilan presentasi bisnis, karena itu sangatlah perlu dukungan berbagai pihak untuk meningkatkan bisnisnya. Untuk mencapainya memerlukan berbagai upaya pendukung, salah satu di antaranya melalui presentasi bisnis, karena memberi kesempatan untuk menjelaskan konsep usaha, keunggulan barang atau jasa yang ditawarkan, serta membangun brand awareness (Pratiwi, 2013). Berdasarkan pengalaman ahli presentasi membuktikan, kesuksesan bisnis sangat besar didukung oleh keterampilan presentasi bisnis (Gallo, 2010).

Keterampilan presentasi bisnis paralel dengan misi pemerintah dalam mengarusutamakan gender. Berdasarkan data IWAPI Jawa Barat tahun 2013, wanita pengusaha yang tergabung dalam IWAPI pada umumnya masuk dalam golongan usaha kecil, karena itu sangatlah perlu dukungan berbagai pihak untuk meningkatkan skala usahanya menjadi lebih tinggi (Ikatan Wanita Pengusaha DPD Jawa Barat, n.d.).

Penelitian ini bertujuan untuk menganalisis persiapan presentasi, penyajian pesan presentasi, dan unsur pendukung presentasi. Selain itu penelitian ini memiliki kepentingan lebih mendalam yaitu agar upaya-upaya peningkatan wanita pengusaha dari berbagai pihak (pemerintah, lembaga usaha, dan pihak yang berkepentingan) akan semakin tepat sasaran dan dirasakan manfaatnya oleh para wanita pengusaha. Dengan demikian wanita pengusaha yang memiliki keterampilan presentasi bisnis diharapkan dapat mempromosikan bisnisnya dengan baik, sehingga dapat meningkatkan volume penjualan produk usaha.

Dalam menjalankan usaha, wanita pengusaha tersebut terkendala berbagai aspek, seperti permodalan, pemasaran, dan pengemasan. Khusus dalam bidang pemasaran, wanita pengusaha diharapkan dapat memanfaatkan peluang usaha, sehingga bisnisnya maju dan berkembang. Untuk menempati hal itu tidaklah mudah, diperlukan berbagai aspek pendukung, di antara kemampuan memresentasikan bisnis kepada calon konsumen untuk memasarkan produk dan jasa terbaik. Melalui presentasi, pengusaha dapat membuka kesempatan menjelaskan konsep usaha, keunggulan produk atau jasa, dan membangun brand awareness (Pratiwi, 2013).

Artikel ini merupakan hasil penelitian mengenai presentasi yang dilakukan oleh wanita pengusaha mencakup penyusunan dan penyampaian presentasi. Presentasi 
yang disampaikan wanita pengusaha diharapkan dapat mengembangkan bisnis dengan baik, sehingga dapat meningkatkan volume penjualan produk dan jasanya.

Penelitian ini mengkaji kemampuan presentasi wanita pengusaha dalam memasarkan produk usaha. Adapun perumusan masalah penelitian yakni bagaimana kemampuan presentasi wanita pengusaha dalam memasarkan produk usaha? (Studi kasus wanita pengusaha pada Ikatan Wanita Pengusaha Indonesia (IWAPI) Jawa Barat. Pendekatan kualitatif digunakan pada penelitian ini, dengan studi kasus tunggal. Keunikan pemilihan studi kasus karena melalui presentasi bisnis wanita pengusaha dapat menyampaikan informasi produk usaha, menjelaskan keunggulannya, dan memromosikan produk usaha sehingga dapat terwujud menjadi penjualan. Selain itu melalui presentasi bisnis yang berhasil memajukan usaha, wanita pengusaha dapat mandiri secara ekonomi.

\section{LANDASAN KONSEP}

\section{Penelitian Terdahulu}

Mark Johlke meneliti tentang "Keterampilan Presentasi Penjualan dan Kinerja Tenaga Penjualan", dimuat dalam Journal of Business and Industrial Marketing, Vol. 21, 2006. Temuan penelitian menunjukkan pengalaman tenaga penjualan, dan pelatihan tingkat yang lebih rendah, mendasari kemampuan presentasi penjualan. Keterampilan tenaga penjualan dalam menggunakan teknik penjualan adaptif dan penutupan terkait dengan peningkatan kinerja. Pengalaman tenaga penjual dan pelatihan untuk mengembangkan keterampilan berkontribusi terhadap kinerja penjualan. (Johlke, 2006)

Penelitian John E. Cicala, Rachel K. Smith, dan Alan J. Bush mengenai "Apa yang membuat presentasi penjualan yang efektif - perspektif pembeli - penjual" dimuat dalam Journal of Business \&
Industrial Marketing, Vol. 27, 2012 (Cicala et al., 2012). Penelitian eksploratif ini bertujuan menguji persamaan dan perbedaan pembeli dan penjual dalam memahami dan mengarakterisasi presentasi penjualan dalam menyajikan tema yang membantu memulai dialog presentasi penjualan efektif mencakup pengetahuan, kemampuan beradaptasi, dan kepercayaan. Keterampilan pembicara dalam presentasi bisnis perlu diupayakan dengan maksimal, seperti latihan, penguasaan topik bahasan, kemampuan menyesuaikan diri dengan lingkungan, dan kedapatdipercayaan pembicara, sehingga khalayak memiliki keyakinan bahwa topik bahasan dari pembicara dapat dipercaya. Dari penelitian tersebut diharapkan dapat memperluas dan memperdalam pemahaman berdasarkan riset yang dilakukan berkaitan dengan presentasi bisnis.

Penelitian yang dilakukan tim peneliti tentang "Karakteristik Khotbah Jumat Di Masjid Kampus" (Studi Deskriptif mengenai Profil Khotib dan Tanggapan Jamaah tentang Khotbah Jumat, di Masjid Al-Asy'ari Universitas Islam Bandung, Perspektif Teknik Presentasi), diteliti oleh Yusuf Hamdan dan Anne Ratnasari. Penelitian ini menganalisis khotbah Jumat mencakup penguasaan khotib terhadap materi, dan penyajian materi khotbah. Sampel penelitian adalah khotib, dan jamaah salat Jumat. Hasil penelitian menunjukkan profil khotib Jumat tidak berusia muda, menjalankan profesi sebagai dosen, memiliki latar belakang pendidikan ganda (jalur pendidikan formal sekolah dan pendidikan pondok pesantren). Khotib menguasai cara berdakwah dan materi khotbah, juga mampu membaca AlQuran dengan fasih, banyak khotib menyampaikan khotbah Jumat yang tidak ringkas. Tanggapan jamaah terhadap topik khotbah Jumat cukup positif, baik mengenai relevansi tema, maupun daya tariknya. Cukup banyak responden yang menyatakan topik kurang aktual dan khotib berbicara 
mengenai tema yang abstrak. (Hamdan, 2007)

Kedua, penelitian "Analisis Komunikasi Nonverbal dalam Presentasi Bisnis" (Studi Deskriptif terhadap Pengusaha Kecil di Kota Bandung), diteliti oleh Anne Ratnasari (Ratnasari, 2009). Penelitian ini menganalisis ekspresi wajah, kontak mata, gerakan tangan, gerakan tubuh, dan penampilan busana para pengusaha dalam menyajikan presentasi bisnis. Hasil penelitian menunjukkan ekspresi wajah, kontak mata, gerakan tangan, dan gerakan tubuh para pembicara perlu dilatih sehingga mereka dapat menggunakannya secara optimal dalam presentasi bisnis, sedangkan penampilan busana yang dipakai mendukung presentasi bisnisnya.

\section{Presentasi Bisnis}

Dalam proses presentasi, terjadi interaksi antara presenter dengan calon konsumen dan sebaliknya. Dilihat dari perspektif komunikasi pemasaran, presentasi masuk pada penjualan tatap muka (personal selling), yaitu presentasi lisan berbentuk percakapan di hadapan satu atau beberapa calon pembeli dengan maksud untuk menjual (Shimp, 2014).

Waringin (2008) menjelaskan penjualan tatap muka berlangsung dalam jaringan sosial pergaulan antarmanusia. Melalui penjualan tatap muka, pengusaha memberikan penjelasan yang terperinci dan mendemonstrasikan produk. Melalui presentasi, pengusaha diharapkan dapat mendukung mengembangkan bisnisnya.

Presentasi dimaksudkan untuk menjelaskan dan mendemonstrasikan produk atau jasa, pesan komunikasi dapat bervariasi sesuai calon pembeli, komunikasi dapat diarahkan kepada calon pelanggan khusus, biaya dapat dikendalikan dengan menyesuaikan jumlah tenaga penjual, dan sangat efektif dalam menghasilkan penjualan serta menumbuhkan kepuasan pembeli (Waringin, 2008).
Persiapan sebelum memulai presentasi, perlu dilakukan pembicara, karena persiapan yang matang menjadi landasan utama dalam presentasi. Landasan lainnya tujuan yang akan dicapai dari presentasi tersebut, dan perilaku apa yang diharapkan dari khalayak (Rakhmat, 2008). Tujuan presentasi penting ditetapkan pembicara sebelum memulai presentasinya, tujuan presentasi antara lain memberi informasi tentang suatu hal, atau bertujuan membujuk, atau menghibur (Hapsari, 2013).

Presentasi terdiri dari tiga bagian yaitu introduksi, inti, dan simpulan. Introduksi harus menjawab empat pertanyaan, antara lain (1) mengapa saya harus mendengarkan presentasi; (2) mengapa saya berkeinginan untuk mempelajari topik yang disajikan; (3) apa yang akan saya dengarkan; (4) apa yang akan saya dapatkan dan manfaatkan dari presentasi. Dalam introduksi, penyaji diharapkan dapat menghubungkan antara topik dan pendengar, dapat memberikan sekilas ulasan sebagai pengantar untuk masuk ke dalam inti topik.

Hal lainnya yang perlu diperhatikan pembicara adalah menetapkan elemen presentasi. Jobs dalam Gallo (2010) menjelaskan, sebuah presentasi yang baik mengandung elemen antara lain headline, pesan kunci, analogi, demonstrasi, partner, kesaksian dari pelanggan, dan klip video. Headline berisi gambaran kasar gagasan yang dituangkan pada kertas atau whiteboard. Ide pada headline berisi 140 karakter atau kurang, mudah diingat, dan ditulis dengan urutan subjek-predikatobjek (Gallo, 2010).

Menurut Jobs dalam Gallo (2010), pesan yang disampaikan kepada pendengar berisi pesan yang telah diatur, yaitu presenter membuat pesan kunci yang berisi tiga pesan yang diinginkan agar diterima audiens. Pesan ini harus mudah diingat tanpa harus melihat catatan lagi. Setiap pesan kunci akan diikuti oleh poin-poin pendukung. Selain itu pembicara yang pandai dalam memilih kata-kata, akan 
mendapat nilai baik dari pendengar. Pemberian pernyataan yang sama oleh presenter dapat menimbulkan kesan yang berbeda, karena perbedaan kata untuk mengungkapkannya. Ahli bahasa mengingatkan, keampuhan bahasa adalah untuk memeroleh asosiasi mental (Abernathy and Reardon, 2001).

Presenter dalam memilih kata-kata dalam presentasi harus jelas, tepat, dan menarik. Kata-kata yang jelas antara lain menggunakan istilah spesifik, sederhana, menggunakan kata dengan hemat, dan mengulang gagasan sama dengan kata yang berbeda (Rakhmat, 2008). Mengapa pemilihan kata demikian penting, karena pemilihan kata tersebut memiliki dampak baik kepada diri sendiri, maupun kepada orang lain. Hal ini sesuai pendapat Chase dalam Urban (2007) menjelaskan "katakata memiliki dampak, kepada orang lain maupun diri sendiri”.

Analogi adalah perbandingan antara dua hal yang berbeda untuk menyoroti bidang-bidang yang sama. Analogi membantu seseorang memahami konsep yang asing baginya (Gallo, 2010).

Demonstrasi mengambil bagian yang besar dalam presentasi, karena audiens ingin melihat, meraba, dan mendapatkan pengalaman dari produk atau jasa anda. Buatlah ia nyata. Jobs berbagi panggung dengan para partner kunci dan dengan produk-produknya. Jobs sering membagi panggungnya dengan orang-orang yang berkontribusi pada kesuksesan Apple (Gallo, 2010).

Menawarkan bukti dari pelanggan atau kesaksian adalah bagian penting dari siklus penjualan. Para pelanggan ingin mendengar kisah sukses. Memasukkan sebuah kutipan, misalnya, merupakan langkah sederhana (Gallo, 2010). Selain itu menggunakan kata-kata yang menyentuh diri khalayak, dan kata-kata tindak (Rakhmat, 2008). Sebagai contoh, pembicara dapat membagikan kata-kata tertentu, seperti kata mutiara untuk menggugah pendengar ingin tahu lebih banyak (Kasali, 2001).
Presentasi yang di dalamnya memasukkan klip video, presentasinya akan berbeda dengan yang lain. Penyaji dapat menampilkan iklan, testimoni karyawan, adegan dari produk itu, atau orang-orang yang memakai produk itu, dan bahkan rekomendasi dari para pelanggan (Gallo, 2010).

Teknik memulai suatu presentasi antara lain menghubungkan langsung antara sasaran dengan topik, menggunakan contoh-contoh dalam kehidupan sehari-hari atau yang sesuai dengan pendengar. Inti topik berisi materi utama yang dibuat secara sistematik, singkat, menarik, dan lengkap. Untuk membantu kelancaran presentasi, presenter dapat merancang suatu kerangka presentasi yang berisikan topik dan sub-sub topik serta gambar, tabel, atau pun kutipan.

Simpulan, merupakan kesan akhir dari pendengar. Simpulan yang terencana harus memberikan kesan akhir yang baik dan dapat menciptakan suasana puas pada pendengar. Dalam simpulan presenter membuat ikhtisar dari keseluruhan presentasi, meninjau kembali sasaran presentasi dan dapat mengundang pendengar untuk mengambil tindakan lebih lanjut.

Sumber informasi yang dapat digunakan yaitu pengetahuan sendiri, berdasarkan pengalaman, pengamatan atau penelitian; pengetahuan dari bahan bacaan seperti koran, majalah, jurnal, peraturan pemerintah dan perusahaan, dan dokumen lain (Ruslan, 2003).

Presentasi yang berhasil perlu persiapan yang tepat, seperti product knowledge bisnis yang dimiliki. Selain itu beberapa hal yang harus dilakukan sebelum presentasi bisnis agar terkoneksi dengan pendengar, antara lain: (1) Praktik; latihan memberikan perasaan nyaman dengan materi yang akan disampaikan. (2) Kenali Situasi Sekitar; penyaji harus membaca situasi, tempat dan acara presentasi dilakukan. Jika penyaji menggabungkan aspek audio visual ke dalam presentasi, bangun koneksi dengan audiens. (3) Kenali 
audiens Anda; poin ini paling penting, tujuan kesempatan berbicara di depan umum adalah untuk benar-benar terhubung dengan audiens. (4) Menyesuaikan konten; pembicara menggunakan kesempatan berbicara untuk menarik perhatian audiens pada bisnis yang ditekuninya (Pratiwi, 2013).

Presenter perlu memperhatikan sistematika pembukaan dan penutupan presentasi. Pembukaan yang baik akan menumbuhkan suasana komunikasi yang positif. Hal itu dapat terwujud dengan langsung menyebutkan pokok persoalan, menghubungkan dengan peristiwa yang tengah diperingati, menghubungkan dengan suasana emosi khalayak, memberikan pujian kepada pendengar, memulai dengan pernyataan, pertanyaan, dan menyatakan kutipan, menceritakan pengalaman pribadi, mengisahkan cerita faktual (Rakhmat, 2008).

Salah satu contoh, presentasi yang menyentuh emosi khalayak adalah presentasi inspirasional, pembicara membagikan pengalaman yang sangat memengaruhinya, pembicara menunjukkan emosinya. Bila ada kegembiraan, dia harus tunjukkan kegembiraannya dalam presentasinya (Daley and Daley-Caravella, 2005).

Selain faktor bakat, yang sangat berpengaruh dalam presentasi adalah latihan, latihan, dan latihan, demikian pernyataan Jobs yang disebut sebagai seorang pembicara memukau membagi kiat-kiat presentasinya (Hapsari, 2013).

Setiap orang mempunyai potensi menjadi pembicara yang baik, cara yang dapat ditempuh antara lain, memelihara kontak visual dan kontak mental dengan khalayak, menggunakan lambang-lambang auditif agar suaranya memberikan makna yang lebih kaya, dan berbicara dengan seluruh kepribadiannya, dan dengan gerak tubuh (wajah, tangan, dan sebagainya) (Rakhmat, 2006). Gerak tubuh (gesture) adalah tindakan yang dapat memiliki makna (Littlejohn and Foss, 2009). Seperti contoh, kontak mata yang dilakukan dengan baik, khalayak akan merasa bahwa pembicara berusaha mendekatkan diri, bersahabat, dan peduli kepada mereka (Lee, 2013).

Gerak tubuh sebagai pesan nonverbal, yaitu penciptaan dan pertukaran pesan dengan tidak menggunakan katakata, tetapi melalui kontak mata, ekspresi muka, kedekatan jarak, dan sentuhan. Rakhmat (2008), mengemukakan alasan pentingnya bahasa tubuh dalam komunikasi, pertama menentukan makna dalam komunikasi antarpribadi.

Menurut Birdwhistell 30\%-35\% makna sosial percakapan atau interaksi dilakukan dengan kata-kata, dan sisanya dilakukan dengan pesan nonverbal. Kedua, perasaan lebih cermat disampaikan lewat pesan nonverbal (bahasa tubuh). Menurut Mahrabian, hanya $7 \%$ perasaan kasih sayang dapat dikomunikasikan dengan kata-kata. Selebihnya, $38 \%$ dikomunikasikan lewat suara, dan $55 \%$ dikomunikasikan melalui ungkapan wajah (senyum, kontak mata, dan sebagainya) (Rakhmat, 2008).

Ketiga, bahasa tubuh memperteguh, melengkapi, dan menggantikan bahasa verbal (Mulyana, 2001). Presentasi sebagai bagian penting dalam bisnis, tatapan mata, gerakan alis yang berlebihan harus dibatasi. Gerakan alis misalnya memberi sinyal, terdapat pertanyaan atau keraguan dari audiens.

Aspek penting yang perlu diketahui pembicara bukan hanya materi presentasi, melainkan "siap dalam melafalkannya, dengan memperhatikan kata-kata yang sedikit sulit dan pengucapannya benar" (Nahusuly, Natanael, 2014).

Dengan demikian (Gallo, 2010) menegaskan dalam membuat halaman presentasi berwarna, dalam satu slide hanya ada tiga poin penting, beri variasi antar slide jika yang pertama berupa tulisan, yang kedua dapat berupa gambar, dan ketiga berbentuk video, dalam setiap 10 menit sekali, tampilkan video lucu dalam presentasi. 


\section{Interaksionisme Simbolik}

Blumer menjelaskan interaksionisme simbolik menganalisis suatu aktivitas yang merupakan ciri khas manusia, yakni komunikasi atau pertukaran simbol yang diberi maknanya (Mulyana, 2002). Interaksi simbolik menganalisis berbagai hal mengenai simbol yang ada di dalam suatu interaksi. Isyarat nonverbal dan pesan verbal yang dimaknai berdasarkan kesepakatan oleh pihak-pihak yang terlibat dalam suatu interaksi, merupakan satu bentuk simbol yang memunyai arti yang penting.

Perilaku seseorang dipengaruhi oleh simbol yang diberikan oleh orang lain, demikian pula perilaku orang tersebut melalui pemberian isyarat berupa simbol. Manusia merespons tidak hanya tindakan orang lain, melainkan juga makna, motif, dan maksud tindakan tersebut (Mulyana, 2002).

Tindakan manusia dalam teori ini didasarkan pada pemaknaan atas sesuatu yang dihadapinya lewat proses selfindication, yaitu proses komunikasi pada diri individu yang dimulai dari mengetahui sesuatu, menilai, memberinya makna, dan memutuskan untuk bertindak berdasarkan makna tersebut (Mulyana, 2002). Karena itu interaksionisme simbolik memusatkan perhatian pada tindakan dan interaksi manusia, bukan pada proses mental yang terisolasi.

Dalam interaksionisme simbolik proses komunikasi berupa informasi dari seseorang kepada orang lain sebagai hasil pemaknaan simbol melalui perspektif sendiri kepada orang lain. Orang tersebut sebagai penerima informasi akan memiliki perspektif khas dalam memaknai informasi yang disampaikan aktor pertama. Di antara mereka terlibat dalam proses saling memengaruhi tindakan sosial.

Berdasarkan

interaksionisme simbolik, wanita pengusaha berinteraksi dengan calon konsumen, konsumen, atau pihak lain melalui makna dan simbol yang mendasari tindakan di antara mereka, dan dengan presentasi bisnis diharapkan dapat memasarkan usahanya dengan baik.

\section{METODE PENELITIAN}

Penelitian ini menggunakan metode penelitian kualitatif. Metode penelitian kualitatif yaitu prosedur penelitian yang menghasilkan data deskriptif berupa katakata tertulis atau lisan dari orang-orang dan perilaku yang dapat diamati (Moleong, 2010).

Inti studi kasus adalah menjelaskan keputusan mengapa studi tersebut dipilih, bagaimana mengimplementasikannya, dan apa hasilnya. Keunggulan studi kasus, menurut (Yin, 2002) antara lain memberi peluang kepada peneliti untuk menelaah secara mendalam, detail, intensif, dan menyeluruh terhadap unit sosial yang diteliti.

Komponen penting dalam desain studi kasus yaitu, pertanyaan penelitian, proposisi jika diperlukan, unit analisis, logika yang mengaitkan data dengan proposisi, serta kriteria untuk menginterpretasi temuan (Yin, 2002). Data dalam penelitian ini berupa kata-kata, dan gambar. Berdasarkan penjelasan tersebut desain studi kasus yang digunakan pada penelitian ini adalah desain kasus tunggal holistik, karena menyajikan suatu kasus unik. Dengan demikian metode penelitian ini adalah studi kasus tunggal di mana peneliti mengamati dan menganalisis kemampuan presentasi dalam memasarkan produk dan jasa.

Informan penelitian adalah wanita pengusaha sebagai pengurus pada Ikatan Wanita pengusaha Indonesia (IWAPI) Jawa Barat. Teknik penentuan sampel secara purposif. Berdasarkan informasi dari Pimpinan dan Pengurus IWAPI Jawa Barat, ditetapkan pengusaha yang memenuhi kriteria untuk mewakili wanita pengusaha IWAPI Jawa Barat. Adapun kriteria yang digunakan unutuk menentukan informan adalah satu, informan memiliki skala usaha kecil dan menengah. Kedua, perusahaan 
informan telah berdiri minimal selama 10 tahun. Ketiga, informan bersedia menjadi sumber data penelitian. Wanita pengusaha yang terpilih adalah mereka yang mewakili pengurus IWAPI Jawa Barat, DPC Kota Bandung, Kabupaten Bandung, Garut, Tasikmayala, Cianjur, Indramayu, dan Cirebon.

\section{HASIL PENELITIAN DAN PEMBAHASAN}

\section{Data Informan Penelitian}

Data penelitian mengenai "Kemampuan Presentasi dalam Memasarkan Produk Usaha" diperoleh melalui wawancara mendalam. Hasil penelitian terhadap profil wanita pengusaha sebagai pengusaha DPD IWAPI Jawa Barat dijelaskan dalam Tabel 1.
Data penelitian mengenai pendidikan wanita pengusaha memperlihatkan wanita pengusaha memiliki pendidikan yang cukup tinggi, dengan pendidikan tersebut cukup mendukung dalam kelancaran usahanya, karena wanita pengusaha yang berpendidikan tinggi memiliki pemikiran yang cukup teruji. Sedangkan mereka yang berpendidikan menengah, sudah berkecimpung dalam bisnis sedari remaja, di mana mereka membantu bisnis orangtuanya. Pertimbangan mereka dipilih sebagai informan, antara lain karena mereka memiliki skala usaha menengah, telah memimpin perusahaan masingmasing cukup lama, sehingga telah memiliki pengalaman dalam mengelola usahanya.

Tabel 1

Profil Informan Penelitian

\begin{tabular}{ccccc}
\hline No & Usia (tahun) & Pendidikan & Jabatan & Jenis Usaha \\
\hline 1 & 42 & S2 & Pemilik Usaha & Biro Jasa Travel \\
2 & 61 & S1 & Pemilik Usaha & Konveksi Pakaian Seragam Upacara \\
3 & 46 & S1 & Pemilik Usaha & Busana Muslim dan Alat Perikanan \\
4 & 52 & D1 & Pemilik Usaha & Catering \\
5 & 50 & SMA & Pemilik Usaha & Catering \\
6 & 58 & D3 & Pemilik Usaha & Catering \\
7 & 45 & D3 & Pemilik Usaha & Pakaian (Celana Legging) \\
8 & 62 & D1 & Pemilik Usaha & Rumah Makan \\
9 & 65 & S1 & Koordinator & Station Radio \\
10 & 36 & S1 & Pemilik Usaha & Catering \\
11 & 53 & S1 & Pemilik Usaha & Jaket Kulit
\end{tabular}

Sumber: Data Peneliti

\section{Persiapan Presentasi}

Untuk mengetahui persiapan presentasi kepada wanita pengusaha ditanyakan sejumlah pertanyaan mengenai persiapan presentasi dalam memasarkan produk usaha, antara lain membuat materi presentasi secara tertulis atau spontan (Rakhmat, 2008). Headline yang berisi gambaran besar gagasan yang dituangkan pada kertas atau whiteboard. Jobs menjelaskan pesan kunci dalam presentasi berisi tentang poin utama yang penting untuk dibahas dalam presentasi. Analogi yaitu presenter menyusun pesan presentasi dengan cara membandingkan dua hal yang berbeda untuk menyoroti bidang yang sama (Gallo, 2010).

Peneliti menemukan sebagian informan menyiapkan materi presentasi secara tertulis dan sebagian lagi tidak menyiapkan presentasi secara tertulis, karena presentasi disampaikan secara spontan. Salah seorang informan, sebagai wanita pengusaha di bidang biro perjalanan yang melakukan persiapan presentasi. 
Persiapan yang dilakukan antara lain menyiapkan powerpoint, video, atau foto demonstrasi biro perjalanan, mempelajari karakter siapa yang akan menjadi kliennya, dan kerapihan diri presenter.

Persiapan presentasi tertulis dilakukan informan antara lain menyiapkan naskah yang akan disampaikan, membuat contoh dan ilustrasi. Informan dalam menyiapkan pesan presentasi berupa catatan singkat yang akan disampaikan kepada audiens misalnya, dalam membuat powerpoint di dalamnya diberi ilustrasi gambar, film, dan audio yang relevan. Tujuan yang ingin dicapai dalam presentasi secara tertulis antara lain agar audiens mengetahui keunggulan produk atau jasa yang dipresentasikan, tertarik, dan bersedia untuk membeli atau menggunakan produk atau jasa yang ditawarkan. Selain itu aspek lainnya yang dipersiapkan presenter adalah fokus pada closing atau penutupan, ketika presenter menyiapkan pesan yang disampaikan kepada calon konsumen dengan meminta kesediaan mereka untuk menggunakan produk atau jasa tersebut dengan memberi sampel gratis, diskon, dan member card dengan fasilitas khusus. Hal itu sebagai penunjang aktivitas presenter dalam mengedukasi calon konsumen mengenai keunggulan produk atau jasa, kemudian cara penggunaan, perawatan, juga keuntungan lainnya dilihat dari kualitas dan harga.

Berdasarkan hasil penelitian sebagian informan yang tidak menyiapkan presentasi secara tertulis atau presentasi yang akan disampaikan secara spontan, informan menyiapkan garis besar presentasi, informan tersebut menyesuaikan pesan presentasi dengan tujuan yang ingin dicapai dalam presentasi tersebut, misalnya persiapan presentasi lisan informan membawa company profile sebagai pelengkap informan yang akan disampaikan pada calon konsumen.

Temuan penelitian lainnya dalam presentasi yang disampaikan secara spontan, informan hanya membawa catatan singkat yang berfungsi sebagai pedoman poin-poin penting yang akan disampaikan pada audiens sebagai bahan pelengkap presentasi tersebut, informan membawa brosur.

Dalam menyusun pesan presentasi secara spontan mengandung isi, tujuan, dan mood. Isi pesan spontan, dalam hal ini pesan direkam secara tersusun, tujuannya untuk menekankan pada hal-hal penting bagi audiens secara singkat. Presenter juga meletakkan mood audiens sebagai hal yang turut mendukung kesuksesan presentasi dengan cara memilih kata-kata yang penuh semangat, singkat, dan membangun hubungan yang akrab dengan audiens.

Hasil penelitian menemukan sebagian besar informan membuat pertanyaan yang isinya penuh semangat yang disampaikan pada audiens, salah satu informan yang memiliki bisnis jaket kulit juga mengatakan bahwa dengan menyampaikan kata-kata yang penuh dengan semangat juga akan terlihat keseriusan calon konsumen dalam meminati barang yang ditawarkan, apalagi jika calon konsumen memiliki pertanyaan mengenai barang tersebut, itu merupakan peluang untuk menjelaskan lebih lanjut mengenai barang yang akan dijual.

Informan biasanya menyusun presentasi dimulai dari pembukaan, isi, dan penutup. Informan juga memberikan penekanan pada hal-hal yang penting bagi audiens, di mana informan membuat slide khusus yang hurufnya lebih besar dan berwarna. Sebagai contoh, dalam pembukaan presentasi bisnis menumbuhkan suasana komunikasi positif dengan menyebut pokok persoalan, menghubungkan dengan peristiwa yang tengah diperingati, misalnya pada peringatan hari Ibu. Selain itu juga menghubungkan dengan suasana emosi (mood) audiens dengan membuat ice breaking, memberi pujian kepada audiens, memberi reward berupa souvenir kecil, menceritakan pengalaman pribadi, mengisahkan cerita faktual, misalnya dengan menceritakan success story seorang teman atau pengusaha, atau bentuk 
penyampaian lainnya, seperti memulai dengan memutar film pendek.

Penelitian menemukan, sebagian besar informan juga membuat headline. Salah satu informan yang memiliki bisnis penjahit pakaian upacara menjelaskan, dalam whiteboard sebagai sarana presentasi, dikemukakan contoh pembuatan pakaian seragam yang digambarkan dalam pola pembuatannya.

Informan lainnya membuat headline berupa kata-kata yang ditulis pada kertas yang berisi inti-inti pembicaraan dalam presentasi sebagai contoh, informan yang memiliki bisnis travel menjelaskan bahwa beliau menulis data sebagai pelengkap presentasi. Data tersebut berupa, jumlah jamaah umrah yang telah berangkat pada 5 (lima) tahun terakhir dijabarkan jumlahnya per tahun. Data jamaah yang berangkat umrah yang diperoleh melalui website, instagram, dan facebook.

Temuan penelitian mengenai pesan kunci dalam presentasi yang digunakan informan adalah pesan yang isinya jelas, sederhana, dan kata-kata digunakan dengan hemat. Misalnya, informan yang memiliki travel umrah menulis pesan kunci dalam presentasinya " $100 \%$ jamaah diberangkatkan". Mayoritas informan mengatakan bahwa mereka membuat pesan kunci dalam presentasi, salah seorang informan mengatakan bahwa dirinya lebih mendetail dalam mengemukakan inti pesan, misalnya mengenai bahan, bagaimana prosesnya dengan bahan yang ada jadi bagus. Lalu mempersilakan menghubungi kami bagi yang kurang atau tidak puas. Hal ini antara lain untuk menjaga kualitas produk usaha.

Temuan penelitian tentang penggunaan analogi dalam presentasi, informan membandingkan dua hal yang berbeda untuk menyoroti topik yang sama. Hal itu dimaksudkan untuk meyakinkan audiens. Sebagai contoh, informan menjelaskan kelebihan produk dari sisi bahan, kekuatan, cara pengerjaan, dan desain. Informan mencari informasi lebih dahulu mengenai produk lain dinilai dari bahan, harga, dan pengerjaannya. Berdasarkan temuan tersebut informan membandingkan produk yang dihasilkannya dengan produk lain, di mana produknya lebih unggul dilihat dari bahan pengerjaan, dan harga.

\section{Penyajian Pesan}

Untuk mengetahui penyajian pesan presentasi kepada wanita pengusaha ditanyakan beberapa pertanyaan penelitian mengenai penyajian pesan presentasi. Pada proses menyampaikan presentasi bisnis, informan memelihara kontak visual dengan audiens (misalnya, presenter mendekatkan diri, peduli kepada audiens, dan sebagainya). Selain itu informan menggunakan gerak tubuh (wajah, tangan, dan sebagainya). Sebagai pelengkap pesan yang disampaikan dalam presentasi. Informan juga memperhatikan sikap audiens (misalnya ekspresi muka, kontak mata, dan sebagainya).

Pada proses menyampaikan presentasi bisnis. Informan menggunakan artikulasi kata, di mana informan berusaha berbicara dengan teratur dan jelas. Informan kadang-kadang menggunakan keragaman nada dan hentian vokal. Selain itu informan menggunakan ritme (tekanan) bunyi kata, atau kalimat, di samping itu informan juga memilih kalimat inspiratif (misalnya, mengutip kata mutiara, dan sebagainya).

Dalam penutupan presentasi bisnis, informan menyimpulkan ikhtisar presentasi. Informan kadang-kadang menyatakan kembali gagasan utama. Hal lainnya, informan mendorong audiens untuk bertindak, misalnya menggunakan atau membeli produk dan jasa yang ditawarkan, misalnya membawa produk yang akan dijual.

Pada saat presentasi spontan, di mana informan hanya menyiapkan catatan singkat, informan menghafal kata demi kata, diingat, untuk melancarkan kalau terjadi tanya jawab. Misalnya, menulis menu makanan, harga, hiasan, atau variasi. Tujuan yang ingin dicapai dalam presentasi 
lisan tersebut agar calon klien mengetahui tentang pelayanan jasa catering yang informan tawarkan. Adapun calon klien yang informan hubungi antara lain ibu-ibu pengajian, kumpulan ibu-ibu arisan.

Penelitian menemukan pada informan menyajikan presentasi tidak terpatok pada bahan yang sudah ditulis pada powerpoint saja, namun informan juga menjalankan presentasi secara spontan. Dalam penyajian presentasi spontan, informan memilih tema yang disajikan sesuai dengan latar belakang pengetahuannya, misalnya informan yang bergerak di bidang tata boga, dari IWAPI DPC Cirebon, selalu mengaitkan tema presentasinya dengan kursus yang pernah dijalaninya yang pernah diikuti di Cirebon pada tahun 1983, dan di Bandung seperti Ny. Liem pada tahun 2002. Apa yang disampaikannya, berusaha untuk menarik perhatian. Contoh pada brosur dan leaflet memuat lengkap spesifikasi menu makanan, sehingga calon konsumen selalu bertanya dan meminta penjelasan. Informan juga berusaha menyesuaikan pembicaraanya dengan tingkat pengetahuan mereka. Contohnya, trend hidangan khas Cirebon pada periode tertentu, informan berusaha menyesuaikan dengan keinginan dan animo masyarakat mengenai hidangan populer di Cirebon. Itu semua juga disesuaikan dengan kondisi calon klien, misalnya pendanaan, lingkungan, dan sebagainya.

Informan juga saat menjelaskan pelayanan produk jasa catering kepada calon klien, disampaikan secara singkat dan padat. Menurut informan, calon klien lebih suka to the point, informan menyampaikan presentasi spontan secara tertib, yang penting-penting bagi calon klien informan. Misalnya infroman menyiapkan rencana presentasi secara lengkap, namun pada pelaksanaannya bergantung konsumen, kalau perhatian konsumen besar dan ingin detil, kami menyampaikan detil juga, seperti menu makanan paket $\mathrm{A}, \mathrm{B}, \mathrm{C}$; harga standar, menengah, dan tinggi.
Saat presentasi tersebut, menurut informan menggunakan Bahasa Indonesia yang di dalamnya memberi fakta. Presentasi yang ada humornya bergantung situasi, bila konsumen menyukai informan menyisipkan humor sedikit, tapi kalau konsumennya serius, informan menyesuaikan dengan keadaan konsumen.

Saat pembukaan presentasi bisnis informan berusaha menumbuhkan suasana komunikasi positif dengan menyebut pokok persoalan, misalnya, mengaitkan dengan isu aktual terkini agar konsumen tertarik terus. Selain itu menghubungkan dengan peristiwa yang tengah diperingati, contohnya bertepatan dengan hari-hari bersejarah, seperti hari Ibu, HUT Kemerdekaan RI, 1 Muharram dengan memberi diskon spesial. Juga menghubungkan dengan suasana emosi (mood) audiens. Contohnya saat perayaan pernikahan, ini hari milik konsumen. Konsumen sukanya apa silakan, perusahaannya akan melayani dengan sebaik-baiknya, bahkan sesuai budget. Informan juga memberi pujian kepada konsumen contohnya, "wah Ibu bajunya bagus sekali", atau "tampilannya cantik sekali".

Hal lainnya yang penting diperhatikan adalah menceritakan pengalaman pribadi, hal itu semata-mata disampaikan untuk meyakinkan konsumen, bukan menonjolkan diri sendiri. Informan juga kadang-kadang menyampaikan kisah cerita faktual dalam presentasi spontan, misalnya, fakta di lapangan tentang kepuasan konsumen diceritakan pula, atau bentuk lainnya seperti bicara tentang keluarga, rekreasi, semata-mata untuk membuat akrab dan suasana cair.

Pada proses menyampaikan presentasi bisnis secara spontan, informan memelihara kontak visual dengan calon konsumen, karena ini penting untuk membangun jaringan. Sebagai contoh dengan konsumen mengadakan pengajian, dan arisan. Informan juga menggunakan gerak tubuh (wajah dan tangan) sebagai pelengkap pesan yang disampaikan dalam 
presentasi, gerakan tersebut mengikuti irama ketika informan berbicara di depan konsumen. Selain itu informan mengikuti keinginan klien, agar tidak terjadi kesalahpahaman. Karena itu sikap calon konsumen sangat kami perhatikan, misalnya, ekspresi muka, kontak mata. Ekspresi wajah, kontak mata calon konsumen menjadi penyemangat dalam memperkirakan penerimaan klien atas presentasi yang disampaikan.

Dalam penutupan presentasi spontan, informan menyimpulkan ikhtisar presentasi, secara singkat untuk mengingatkan, dan mengulang kata atau kalimat yang telah disampaikan. Kadangkadang menyatakan kembali gagasan utama, dan mendorong calon klien untuk bertindak, misalnya menggunakan atau membeli produk dan jasa yang ditawarkan. Karena itu informan membagi brosur, dibarengi pula dengan pendekatan personal agar konsumen jadi menggunakan jasa catering yang ditawarkan.

Informan menganggap, powerpoint sebagai pegangan aspek-aspek apa saja yang akan disampaikan kepada calon klien. Dalam presentasi tersebut, informan menyelipkan beberapa kata yang dapat menjadi motivasi bagi calon klien. Misalnya, informan yang memiliki bisnis travel menggunakan tagline biro perjalanan seperti "Sahabat Anda Menuju Baitullah". Selain itu informan juga mengaku selalu menekankan mengenai visi dan misi dari biro perjalanan yang dipimpinnya tersebut.

\section{Unsur Pendukung Presentasi}

Untuk mengetahui unsur pendukung presentasi, kepada wanita pengusaha ditanyakan sejumlah pertanyaan mengenai presentasi untuk memasarkan usaha, antara lain penggunaan demonstrasi produk atau jasa, mengajak orang lain sebagai partner yang turut menjelaskan kinerja produk atau jasa, melibatkan kesaksian pelanggan, dan penggunaan video serta foto dalam presentasi. Hal ini sesuai dengan pendapat Jobs dalam (Gallo, 2010) menjelaskan sebuah presentasi yang baik mengandung unsur pendukung antara lain: demonstrasi, partner, kesaksian dari pelanggan, video, dan foto.

Temuan penelitian mengenai penggunaan demonstrasi dalam presentasi, informan menjelaskan bahwa demonstrasi untuk memperjelas presentasi yang disampaikannya. Mereka berpendapat, demonstrasi bergantung pada situasi dan kepentingan. Para pemesan dengan jumlah banyak atau partai besar, biasanya meminta presentasi dan demo (memetakan). Pemesan dalam jumlah kecil, presentasinya sederhana seperti percakapan antarpribadi. Sebagai contoh demonstrasi yang dilakukan oleh pengusaha jasa jahit pakaian upacara tentang letak kancing, pemasangan pangkat (untuk seragam militer), dan model seragam yang sudah jadi selalu informan bawa. Tipe demonstrasi yang dilakukan melalui penayangan video selama perjalanan umrah, dalam video tersebut diperlihatkan bagaimana proses perjalanan hingga keadaan selama menjalani ibadah umrah.

Mengenai partner kerja, sebagian informan mengajak pihak lain sebagai partner yang turut menjelaskan kinerja produk atau jasa dalam presentasi. Partner ini biasanya pemesan yang telah menaruh kepercayaan kepadanya, juga menyuplai bahan yang juga informan percayai. Dihadirkannya partner memiliki tujuan antara lain untuk berbagi panggung dengan orang yang berkontribusi, orang yang memberi bukti dari pelanggan dan rekomendasi dari pihak ketiga. Seperti salah satu informan pemilik bisnis telur asin yang mengaku, ada konsumen setianya yang juga membantu menjelaskan dan meyakinkan produk terhadap calon konsumen. Namun selain partner dari pihak eksternal, ada juga yang melibatkan pihak internal seperti pegawai yang sudah menguasai produk yang akan ditawarkan untuk membantu menjelaskan dan meyakinkan calon konsumen.

Hasil penelitian mengenai kesaksian pelanggan dalam presentasi, sebagian informan melibatkan kesaksian pelanggan 
sebagai pengguna produk atau jasa perusahaannya. Pelanggan tersebut suatu saat diajaknya untuk ikut memerkuat produknya. Selain melibatkan kesaksian pelanggan secara langsung, ada informan yang menggunakan media sosial untuk menjadi media kesaksian pelanggannya, hal itu dilakukan oleh informan pemiliki jasa travel umrah yang mengunggah video kesaksian atau testimonial dari pelanggan mengenai kesan selama melakukan perjalanan dengan travel tersebut (Rabbani Tour dan Travel, 2016).

Penggunaan video dan foto, menurut sebagian informan dalam presentasi menggunakan media komunikasi untuk mendukung presentasi produk atau jasa yang disampaikan pada calon konsumen. Informan yang memiliki bisnis jahitan, berpendapat media komunikasi tersebut disesuaikan dengan kebutuhan, dan bergantung pada audiens atau calon pelanggan. Audiens yang serius ingin presentasi tentu peralatan yang dibawa lebih lengkap. Media yang digunakan informan untuk mempresentasikan materi kepada audiens di antaranya adalah video dan foto.

\section{Pengelolaan Bahasa Tubuh}

Untuk mengetahui pengelolaan bahasa tubuh dalam presentasi, kepada wanita pengusaha ditanyakan sejumlah pertanyaan mengenai kontak visual, ekspresi wajah, dan gerakan tangan ketika melakukan presentasi bisnis. Hal ini sesuai dengan pendapat (Rakhmat, 2008), setiap orang memunyai potensi menjadi pembicara yang baik, cara yang dapat ditempuh antara lain, memelihara kontak visual, dan gerakan tubuh (wajah dan tangan).

Temuan penelitian mengenai kontak visual, informan mengaku saat presentasi sering melakukan kontak visual. Hal ini bertujuan untuk mengetahui respon audiens terhadap presentasi yang disampaikan. Sebagai contoh informan pemilik usaha catering asal Kota Kuningan berpendapat bahwa melihat respon klien yang puas dapat dilihat dari respon matanya yang berbinar.

\section{PENUTUP}

\section{Simpulan}

Wanita pengusaha memiliki kemampuan presentasi dalam memasarkan produk usaha. Presentasi tersebut terdiri dari: menyiapkan materi presentasi tertulis, spontan, dan membuat headline.

Penyajian pesan presentasi terdiri dari: pengantar, isi, dan simpulan. Presenter juga harus memiliki kemampuan dalam menyampaikan presentasi dengan artikulasi kata yang teratur serta jelas.

Unsur pendukung presentasi, presenter menggunakan demonstrasi produk atau jasa yang melibatkan kesaksian pelanggan dan penggunaan video serta foto.

Wanita pengusaha mengelola bahasa tubuh yang digunakan untuk melengkapi presentasi antara lain dengan kontak visual, ekspresi wajah, dan gerakan tubuh (wajah dan tangan).

\section{Saran}

Presenter diharapkan dapat menyiapkan dan menyajikan presentasinya dengan baik melalui persiapan presentasi secara tertulis maupun spontan. Penyajian pesan presentasi tersebut dapat berjalan lancar apabila presenter melakukan latihan yang terus-menerus, menyajikan presentasi dengan mempelajari isi materi dan teknik penyampaiannya sebagai presenter dapat menyampaikan materi presentasi untuk membangun brand awareness produk usaha.

\section{DAFTAR PUSTAKA}

Abernathy, R. and Reardon, M. (2001). 25 Kiat Dahsyat Menjadi Pembicara Hebat. Bandung: Mizan Pustaka.

Cicala, J. E., Smith, R. K. and Bush, A. J. (2012). What makes sales presentations 
effective - a buyer-seller perspective. Journal of Business \& Industrial Marketing, 27 (2), p.78-88. [Online]. Available at: doi:10.1108/08858621211196958.

Daley, K. and Daley-Caravella, L. (2005). Speaking Mastering: Strategi Menguasai Presentasi yang Efektif. Jakarta: PT. Bhuana Ilmu Populer.

Gallo, C. (2010). Rahasia Presentasi Steve Jobs: Bagaimana Tampil Luar Biasa Hebat di Depan Setiap Audiens. Jakarta: Erlangga.

Hamdan, Y. (2007). Karakteristik Khutbah Jumat di Mesjid Kampus: Perspektif Komunikasi. MediaTor (Jurnal Komunikasi), 8 (2), p.353-368.

Hapsari, E. (2013). 6 Tips Presentasi Dahsyat Ala Steve Jobs. [Online]. Available at: http://www.republika.co.id/berita/humai ra/sana-sini/13/10/30/mvh0rk-6-tipspresentasi-dahsyat-ala-steve-jobs [Accessed: 11 October 2016].

Ikatan Wanita Pengusaha DPD Jawa Barat. (n.d.). Data Wanita Pengusaha IWAPI Jawa Barat 2013. [Online]. Available at: http://iwapijawabarat.com/ [Accessed: 20 April 2016].

Johlke, M. C. (2006). Sales presentation skills and salesperson job performance. Journal of Business \& Industrial Marketing, 21 (5), p.311-319. [Online]. Available at: doi:10.1108/08858620610681614.

Kasali, R. (2001). Sukses Melakukan Presentasi. Jakarta: PT. Gramedia Pustaka Utama.

Lee, C. (2013). Presenter Handbook: Dalam Pembuatan, Persiapan, Sampai Presentasi. Jakarta: PT. Elex Media Komputindo.

Littlejohn, S. W. and Foss, K. A. (2009). Teori Komunikasi. Jakarta: Salemba Humanika.

Moleong, L. J. (2010). Metodologi Penelitian Kualitatif. Bandung: PT. Remaja Karya.

Mulyana, D. (2001). Pengantar Ilmu Komunikasi. Bandung: PT. Remaja Karya.

Mulyana, D. (2002). Metode Penelitian Kualitatif. Bandung: PT. Remaja Karya.
Nahusuly, A. N. (2014). Tips Membuat Orang Tertarik Dengan Presentasi Anda. [Online]. Available at: http://intisarionline.com/Career/Tips-MembuatOrang-Tertarik-Dengar-PresentasiAnda.

Pratiwi, H. (2013). 5 Tips Presentasi untuk Pebisnis Pemula. [Online]. Available at: http://tekno.kompas.com/read/2013/01/2 2/21001190/5.tips.presentasi.untuk.pebi snis.pemula [Accessed: 22 January 2016].

Rabbani Tour dan Travel. (2016). Testimonial dari Pelanggan Bandung. [Online]. Available at: https://rabbanitour.com/category/testim oni-umroh/ [Accessed: 9 August 2016].

Rakhmat, J. (2006). Psikologi Komunikasi. Bandung: PT. Remaja Rosdakarya.

Rakhmat, J. (2008). Retorika Modern: Pendekatan Praktis. Bandung: PT Remaja Rosdakarya.

Ratnasari, A. (2009). Analisis Komunikasi Nonverbal dalam Presentasi Bisnis. Riset Tidak Dipublikasikan. Bandung.

Ruslan, R. (2003). Metode Penelitian Public Relations dan Komunikasi. Jakarta: PT. Raja Grafindo Persada.

Shimp, T. A. (2014). Periklanan Promosi. Jakarta: Erlangga.

Sukiswanti, P. (2014a). Anggota Iwapi 60\% Pengusaha Kecil Menengah. [Online]. Available at: http://ekbis.sindonews.com/read/928215 134/anggota-iwapi-60-pengusaha-kecilmenengah-1416804176.

Sukiswanti, P. (2014b). Jelang MEA, Iwapi Minta Pemerintah Beri Pelatihan. [Online]. Available at: http://ekbis.sindonews.com/read/928405 /34/jelang-mea-iwapi-mintapemerintah-beri-pelatihan-1416819219.

Urban, H. (2007). Positive Words, Powerful Results. Jakarta: PT. Bhuana Ilmu Populer.

Waringin, T. D. (2008). Marketing Revolution. Jakarta: PT. Gramedia Pustaka Utama.

Yin, R. K. (2002). Studi Kasus (Desain dan Metode). Jakarta: PT. Raja Grafindo Persada. 